\title{
Spectacle and Secrecy: Press Coverage of Conjoined Twins in 1950s Britain
}

\author{
KELLY LOUGHLIN*
}

In the early 1950s, when the National Health Service (NHS) was still in its infancy, the British public was gripped by news reports of two attempts at the surgical separation of conjoined twins. The first operation involved one-year-old twin girls from Kano, Nigeria. The twins were xiphopagus (joined at the lower sternum) and shared a liver, separation was attempted at London's Hammersmith Hospital in December 1953. One child survived. In February 1955 news broke of the birth of craniophagus twins (joined at the head) in Keighley, West Yorkshire. Separation of the month-old girls was attempted at London's University College Hospital, but neither child survived.

Today, medical ethics and disability-politics increasingly provide the matrix for public debate about the surgical separation of conjoined twins. "Sacrifice surgery" is the term now used to describe interventions that will inevitably result in the death of one child. ${ }^{1}$ Even in cases where separation does not imply sacrifice, the emergence of new perspectives on "disability" are now questioning the assumption that separation is a preferable state. ${ }^{2}$ The public debate provoked by the Kano and Keighley cases was the product of a markedly different context. The ethics of the procedure itself were never an issue, because the conditions for the possibility of such a debate had yet to arrive. ${ }^{3}$ Ethical concerns were mobilized in relation to the Kano and Keighley cases, but they focused exclusively on the nature of medicine's own professional ethics and matters of confidentiality. What prompted these specific concerns was the intense level of press interest in the twins and the medical personnel involved in the operations. In the context of the 1950s it was medical communication rather than surgical separation that was considered controversial, unethical and in need of regulation.

The Kano and Keighley cases open up a number of interesting questions about British medicine in the early years of the NHS. In what ways did the new service, and its nationalized hospitals, impact on the nature and development of medicine's professional ethics, or on relations between the medical profession and the popular press? These questions were raised in debates about press coverage of the twins; it was the popular representation of these cases that became the source of controversy and a site

(C) Kelly Loughlin 2005

* Kelly Loughlin, MA, PhD, Centre for History in Public Health, Public and Environmental Health Research Unit, London School of Hygiene \& Tropical Medicine, Keppel Street, London WC1 7HT, UK. Kelly.Loughlin@1shtm.ac.uk

\footnotetext{
${ }^{1}$ A D Dreger, 'The limits of individuality:
} ritual and sacrifice in the lives and medical treatment of conjoined twins', Stud. Hist.
Phil. Biol. Biomed. Sci.,1998, 29 (1): $1-29$.

${ }^{2}$ Y Michael Barilan, 'Head counting vs heart counting: an examination of the recent case of the conjoined twins from Malta', Perspect. Biol. Med., 2002, 45 (4): 593-603; C Myser and D L Clark, "Fixing" Katie and Eilish: medical documentaries and the subjection of conjoined twins', Lit. Med., 1998, 17: 45-67.

${ }^{3} \mathrm{R}$ Cooter, 'The resistable rise of medical ethics', Soc. Hist. Med., 1995, 8: 257-70. 


\section{Kelly Loughlin}

for mobilizing claims about ethical behaviour. Matters of communication, informationcontrol and "image-management" were therefore an important and potentially problematic aspect of the new service. These questions are examined here through a range of documents, including press reports, the minutes of a confidential enquiry into the press coverage convened by the British Medical Association (BMA), oral and written testimony supplied to the enquiry, and accounts written after the event by key participants. The controversy over the representation of these cases emerges as an important episode in the development of the relationship between medicine and the media in post-war Britain, and highlights the distinction accorded to doctors and hospitals as sources of "medical news" due in large part to claims about confidentiality.

The spectacle and secrecy aroused by the two operations opens up an area which is best analysed through a number of overlapping frames. Sociological analyses of mass media provide the idea of "source-media relations". ${ }^{4}$ As the term suggests, it seeks to highlight the role of media sources (press officers, public relations personnel, campaigners and a range of "experts") and place them in dynamic relationship with media producers (journalists, editors, news organizations). Recent studies have demonstrated the importance of source strategies in accounting for the news agenda $v i s$ - $a$-vis HIV/AIDS and environmental issues in the UK. ${ }^{5}$ A similar, sociologically derived frame, specific to scientific culture, has been developed by Stephen Hilgartner. Hilgartner's work on America's National Academy of Science moves beyond an analysis of texts to explore the "social machinery of information control", through which expertise and scientific credibility is publicly performed, maintained or contested, through the use of techniques like the press release and press conference. $^{6}$

These frames point to the centrality of a dynamic, social machinery of information control, which is essential to the public communication of expert knowledge claims in contemporary, media-soaked cultures. Historically, however, we know very little about the development of source-media relations over time. ${ }^{7}$ On the other hand, Hilgartner's dramaturgical perspective, through which contemporary scientific expertise is "publicly performed" suggests an obvious link with older traditions of medical showmanship when surgery and clinical demonstration were forms of public theatre. ${ }^{8}$ Here, I argue that the

\footnotetext{
${ }^{4}$ On source-media relations, see P Schlesinger, 'Rethinking the sociology of journalism: source strategies and the limits of media-centrism', in M Ferguson (ed.), Public Communication, London, Sage, 1990, pp. 122-57.

${ }^{5}$ D Miller and K Williams, 'Negotiating HIV/AIDS information: agendas, media strategies and the news', in J Eldridge (ed.), Getting the message: news, truth and power, London, Routledge, 1993, pp. 126-43; D Miller, J Kitzinger, K Williams and $\mathrm{P}$ Beharrell, The circuit of mass communication: media strategies, representation and audience reception in the AIDS crisis, London, Sage, 1998; A Anderson, 'Sourcemedia relations and the production of the environmental agenda', in A Hansen (ed.), The mass media and environmental issues, Leicester University Press, 1993, pp. 51-68; A Anderson, Media, culture and the environment, London, UCL Press, 1997.
}

\footnotetext{
${ }^{6}$ S Hilgartner, Science on stage: expert advice as public drama, Stanford University Press, 2000; K Loughlin, 'The theatre of scientific authority' (essay review), Studs. Hist. Phil. Biol. Biomed. Sci., 2003, 34: 375-80.

${ }^{7}$ See, for example, D Miller and W Dinan, 'The rise of the PR industry in Britain, 1979-1998', Eur. J. Commun., 2000, 15: 5-35. Information on the development of PR in British medicine is contained in, K Loughlin, 'Publicity as policy: the changing role of press and public relations at the BMA, 1940-1980', in V Berridge (ed.), Making health policy: networks in research and policy after 1945, Amsterdam, Rodopi, forthcoming 2005, pp. 277-96.

${ }^{8}$ On dissection as public spectacle, see R Richardson, Death, dissection and the destitute, London, Phoenix, 2001; on clinical showmanship, see A Winter, 'Ethereal epidemic: mesmerism and the
} 


\section{Press Coverage of Conjoined Twins in 1950s Britain}

Kano and Keighley cases resonate with these older traditions, but the furore they caused also points forward to a newer emergent machinery of source-media relations characteristic of the post-war years.

\section{The Glare of Publicity: Patients and Surgeons in the Press}

The case of the Kano twins and that of the Keighley twins were very different, in terms of the families involved and the outcome of the medical interventions. These stories became inextricably linked, however, through the involvement of Professor Ian Aird, Head of Surgery at London's Hammersmith Hospital. Aird led the surgical team that performed the operation on the Kano twins and, although he was not directly involved in the second operation, he had personal connections with the family. Aird became a key player in the controversy which developed over press activity surrounding the two cases; much of the available documentary evidence concerning these events is contained in the several accounts he produced. He sent a report detailing press intrusion to the Central Ethical Committee (CEC) of the British Medical Association (BMA); he took his complaints to the letters pages of the British Medical Journal and the national press; and the episode was covered in a chapter of his biography. ${ }^{9}$ From these and other available accounts there emerges a picture of fierce struggles to control stories of surgical success and failure and the celebrity attending them.

In the case of the Kano twins, an ex-Hammersmith student, working in Nigeria, seems to have informed Aird of the twins' condition. The father of the twins worked for the United Africa Company (UAC) and this commercial organization paid for the girls and their mother to fly to London. There is no evidence of how the press knew about the arrival of the family and the purpose of their visit. Interestingly, UAC also offered the services of their press office to handle any publicity arising from the case. Journalists and photographers greeted the arrival of the Nigerian family at the airport and became a permanent presence at the hospital throughout their stay. The front page of the Fulham \& Hammersmith Advertiser declared on 21 November 1953, "SiAMESE Twins ARE IN HAMmERSMith Hospital-Tests being carried out with a view to separation". ${ }^{10}$ On the day of the operation (3 December) the fate of the Kano girls gripped the nation's attention. Members of the public joined the press throng outside Hammersmith Hospital waiting to hear news of the outcome and meet copy deadlines for the afternoon editions. Less acceptable, however, were episodes in which journalists and photographers entered the hospital wearing white coats and managed to convince a matron they were working there. In this way they

introduction of inhalation anaesthesia to early Victorian London', Soc. Hist. Med., 1991, 4: 1-27.

${ }^{9}$ Records of the Joint Conference of the Representatives of the Press and the Medical Profession, 1955-56, Archives of the British Medical Association, BMA House, London (hereafter Records of the Joint Conference). Aird's correspondence is contained in Exploratory meeting held 29th March 1955, notes for advance meeting of medical side (private and confidential), PR (press) B, summary of preceding events; PR (press) C3, comments and correspondence in press, British Medical Journal, Daily Telegraph 1955, general press comments, miscellaneous comment. 'Press publicity', letter from I Aird, Br. med.J., 1954, i: 153; 'Doctors and the press', letter from I Aird, Br. med. J., 1955, i: 1028-9; $\mathrm{H}$ McLeave, A time to heal: the life of Ian Aird, the surgeon, London, Heinemann, 1964.

${ }^{10}$ Fulham \& Hammersmith Advertiser, Sat., 21 Nov. 1953, p. 1. 


\section{Kelly Loughlin}

obtained photographs of the children, which subsequently appeared in the press; hospital windows had to be blacked out to prevent further surreptitious picture-taking. Under the banner headline "The Twins Night CRIsIs—one dies, battle for the other continues", the Daily Sketch's front page of 4 December showed photographs of both twins, their mother, and $\mathrm{Mr} \mathrm{H}$ Woodford Davies, the anaesthetist, as he left the hospital. ${ }^{11}$ Aird too became the focus of press attention. Police were called to clear journalists who besieged his home and that of his elderly parents - the latter had been asked for photographs of the celebrity surgeon. Furthermore, according to Aird, the mother of the twins was so alarmed at press reports of the dangers of the operation that she had considered withdrawing and returning to Nigeria. ${ }^{12}$

These and other incidents prompted Aird to write to the BMA's ethical committee, setting-out what had happened, and to write to the British Medical Journal suggesting ways of managing the press interest. The journal responded with an editorial on 'The press and the profession'. ${ }^{13}$ Aird's need to set the record straight with the BMA was necessitated by the rule of professional anonymity which governed doctors' relationship with the media at this time. This rule and its management were also addressed in the British Medical Journal letter and editorial. Professional anonymity was enshrined in the ethical guidelines of the General Medical Council (GMC)—namely its edict against indirect advertising, a practice deemed ungentlemanly and likely to bring the profession into disrepute. ${ }^{14}$ The edict against indirect advertising emerged at the close of the nineteenth century as a character-based marker of professional values, serving to distinguish and demarcate doctors from unlicensed practitioners: medicine was a gentlemanly profession, not a trade to be plied through open competition in the marketplace. Anonymity had to be maintained when dealing with the media, and allowing oneself to be named in the press could and did lead to accusations of unfair advantage and result in a hearing before the GMC for the publicity-seeking doctor. This rule was supported by the ethical committee of the BMA throughout the 1950 s and beyond. ${ }^{15}$

However, Aird's brush with publicity did not end with the departure of the surviving Kano twin, as news broke just a year later (January 1955) of conjoined twins born in Keighley, West Yorkshire. These twin girls were at the opposite end of the social spectrum from the Kano twins. Born into a family with strong medical connections, the twins left Yorkshire for London, and surgery, within a month of their birth, just as the press got wind of their existence. In this case the parents and the doctors demanded and expected complete anonymity, entering into elaborate ruses to conceal the whereabouts of the children.

\footnotetext{
${ }^{11}$ Daily Sketch, Frid., 4 Dec. 1953, p. 1.

${ }^{12}$ McLeave, op. cit., note 9 above, pp. 176-94.

${ }^{13}$ Letter from I Aird, Br med.J., 1954, i: 153; 'The press and the profession', Br. med. J., 1954, i: 141-2.

${ }^{14} \mathrm{R}$ G Smith, 'The development of ethical guidance for practitioners by the General Medical Council', Med. Hist., 1993, 37: 56-67; A A G Morrice, " "The medical pundits": doctors and indirect advertising in the lay press, 1922-1927', Med. Hist., 1994, 38: $255-80$.

${ }^{15}$ A A G Morrice, "Honour and interests": medical ethics in Britain, the work of the
}

\author{
British Medical Association's Central Ethical \\ Committee, 1902-1939', MD thesis, London \\ University, 1999. See also, 'Report of Council on \\ indirect methods of advertising', Br. med. J., \\ 1953, i: supplement, pp. 126-8; and the Central \\ Ethical Committee's discussion of the topic in, \\ 'Proceedings of Council', Br. med. J., 1956, i: \\ supplement, pp. 47-53, on pp. 49-51. On the \\ embargo against advertising at this time in the North \\ American context, see R L Martensen, 'Physician \\ advertising', J. Am. Med. Assoc., 1994, \\ 272: 1623.
}




\section{Press Coverage of Conjoined Twins in 1950s Britain}

The brother of the twins' father was a Harley Street surgeon and close friend of Aird. Initially the twins were brought to Harley Street for examination where arrangements were made, on Aird's suggestion, for Geoffrey Knight, a neurosurgeon at Brook Hospital, Woolwich, to attempt separation. The press descended on Harley Street and the children were smuggled out through a side entrance while journalists gave chase to a "dummy" car. Another change of cars took place but the children never reached the Brook Hospital. Knight withdrew from the operation citing the pressure of press activity as his reason. Aird then persuaded Mr Julian Taylor to attempt the surgery at University College Hospital $(\mathrm{UCH}){ }^{16}$

The surgery was not successful and both children died. Following the operation, a hospital administrator issued a statement to the Press Association on 23 February 1955 suggesting that press activity had influenced the outcome. This accusation provoked furore in the press. Under the headline "Tragedy of the Siamese twins", the Daily Mirror reported that Mr Julian Taylor saw the statement as "ridiculous", and continued: "Mr Geoffrey Knight stated last night that neither he nor Professor Aird was consulted before the statement was made". Sir Alexander Maxwell, chair of the governors at UCH was quoted as saying, "I don't think anyone, certainly not my hospital, could possibly blame the Press for the unfortunate death of these twins". Kenneth Robinson, Member of Parliament for the borough served by UCH, a doctor and member of the North West Metropolitan Hospital Board, added, "I cannot believe that any hospital would be deflected from doing what is best for its patients by any outside circumstances such as comment or action by the Press". ${ }^{17}$ It would seem that the statement was badly handled and issued without due consultation. Nevertheless, the flurry of headlines, accusations and confusion that followed prompted Aird to give a named interview to the Observer on 27 February 1955, an event which pushed the BMA into action. ${ }^{18}$

The BMA sought to address the problem of the press and the profession by convening a conference, the Joint Conference of the Representatives of the Press and the Medical Profession. ${ }^{19}$ The Conference met six times between April 1955 and May 1956, with an initial exploratory meeting taking place at the end of March 1955. Medical relations with the press and with broadcasting had been monitored for some time by the Association's Central Ethical Committee (CEC) and its Public Relations Committee (PRC). However, pressure for a meeting with key elements in the newspaper industry came in this instance from representatives of hospital based medicine, the BMA's Consultants Committee (CC). After all, it was hospital news at issue, news that affected a powerful group within the BMA and the NHS. Members of the CC, the CEC and the Council of the BMA participated in the Joint Conference, organized largely by John Pringle, head of the BMA's press office and chaired by Sir Guy Dain of the PRC. ${ }^{20}$ Sir Linton Andrews, editor of the Yorkshire Post and chair of the new Press Council led the assembled representatives

\footnotetext{
${ }^{16}$ These events are detailed in McLeave, op. cit., note 9 above, pp. 192-4, and in Records of Joint Conference, 29 March 1955, PR (press) B, summary of preceding events.

17 'Tragedy of the Siamese twins', Daily Mirror, 26 Feb. 1955, press clipping contained in Records of the Joint Conference, PR (press) C3.
}

\footnotetext{
${ }^{18}$ Records of the Joint Conference, 29 March 1955, PR (press) C3, general press content, 1955.

${ }^{19}$ The BMA issued the invitation on 8 March 1955.

${ }^{20}$ On John Pringle and the BMA press office at this time, see K Loughlin, 'Your life in their hands: the context of a medical-media controversy', Media Hist., 2000, 6: 177-88.
} 


\section{Kelly Loughlin}

of the press: National Union of Journalists, Institute of Journalists, Press Association, Newspaper Society, Guild of British Newspaper Editors, Periodical Proprietors' Association, and Newspaper Proprietors' Association. The Ministry of Health was represented by their press officer, Stephen Heald, although his position was that of an observer. BBC Radio and BBC Television Talks were also represented, but their input was minimal.

Through its deliberations on evidence and opinions presented by representatives of both professions, the Joint Conference formulated a "routine procedure" for the release of information from hospitals. This was accepted by the Ministry of Health and issued as a circular to hospital management boards in July 1956. ${ }^{21}$ The circular and an "explanatory memorandum" offered guidelines on the form and timing of information released from hospitals to the press, and recommended that each hospital or group of hospitals should designate an appointed person to deal with press inquiries, a system already operating in some hospitals. The importance of this position was emphasized by the statement that "on no account should this duty be left to porters, telephone operators, or junior medical, nursing or clerical staff". The circular urged that the appointed people build relationships with the local press, and offered suggestions such as a rota of designated contacts to provide twenty-four-hour cover, and that the accreditation of journalists who appeared unannounced at the hospital be checked. The patient's right to confidentiality was the principle governing the release of any information, managed in relation to the practicalities of different cases. Ordinarily, the communication of any information above a simple acknowledgement that a certain person had been admitted to the hospital, along with a brief comment on his/her condition (poorly, comfortable, doing well) rested with the patient, and his/her consent was required. Indeed, even in cases where the patient's presence in the hospital was common knowledge, if he/she asked the hospital to deny it then "no comment" was described as the safest response to inquiries. ${ }^{22}$

With its emphasis on the primacy of the patient's right to confidentiality, the routine procedure could be seen as the triumphal outcome of the saga of the twins, the press interest they attracted, and the efforts of Aird to protect his and their privacy. Indeed, this much is claimed in Aird's biography, where his criticism of the press "caused the British Medical Association to convene a representative meeting ... The surgeon's recommendations about the patient's and the doctor's rights were written into a code of behaviour which hospital and journalists could follow in cases like that of Siamese twins". ${ }^{23}$ Looked at in this way, the episode has a timeless quality about it, a familiar tale of press sensationalism and the intrinsic newsworthiness of a novel surgical procedure. However, an element of historical and contextual specificity snags the sense of timelessness and inevitability attributed to events that attract the epithet "media circus". At this time the confidentiality question regarding media coverage of medicine had two aspectsconfidentiality and professional anonymity. The specifics of this professional ethic are

\footnotetext{
${ }^{21}$ Routine procedure for the release of information from hospitals, Ministry of Health circular number HM (56) 58. The text of this circular was printed in the British Medical Journal, 'Doctors and the press, news about hospital patients', Br. med. J., 1955, ii: supplement, pp. 100-2 ; see also 'Hospitals and the press: recommended routine at hospitals, Monthly
}

Circular of the Newspaper Society, Aug. 1956, pp. 197-8.

${ }^{22}$ Routine procedure, op. cit., note 21 above;

'Doctors and the press', Br. med. J., 1955,

ii: supplement, p. 101.

${ }^{23}$ McLeave, op. cit., note 9 above, p. 194. 


\section{Press Coverage of Conjoined Twins in 1950s Britain}

central to understanding the saga of the twins as a key episode in the development of medical-media relations in Britain.

\section{Keeping Secrets and Telling Stories}

In the context of the 1950 s, professional anonymity was as important a means of controlling information as patient confidentiality. In shunning personal publicity and demanding anonymity for medical practitioners, this rule helped to foster a particular public image of medicine: as the impersonal, disinterested voice of expertise. This image was endangered during the saga of the conjoined twins, as surgical celebrity proved difficult to manage. Aird's interview with the Observer, which came after a year in which his name had become inextricably linked with the spectacle of conjoined twins, ran the risk of being taken as an exercise in self-promotion, "Oh, Ian's at it again ... making capital out of Siamese twins". ${ }^{24}$ Aird's actions however were not so much an attempt to court popular publicity but to control the representation of a high profile surgical event.

Patient confidentiality and professional anonymity had very different fortunes in the Kano and Keighley cases. Indeed, members of the Joint Conference who heard Aird's evidence noted the "apparent inconsistency between his respective attitude to the two cases". ${ }^{25}$ The precise nature of this inconsistency is unclear, but presumably the reference is to the layers of social, colonial and ethnic difference that structured Aird's presentation. For example, it is clear that the Kano family had much less control over their story than the Keighley family. The involvement of a commercial company and its press office signal the capital that could be made from the conjoined twins, and their arrival in London was certainly not a secret. Aird praised the work of the United Africa Company, stating that the "situation improved immeasurably" once he had taken up the offer of their public relations office:

I satisfied ethical requirements by not giving any information whatever to the press directly but by giving the company concerned a report of their patient from time to time ... at their discretion they furnished what particulars they thought were suitable to the press ... [and] ... my hospital and I could have remained anonymous if the press had not already been in possession of my name before the arrangement [with the press office]. ${ }^{26}$

Despite the UAC's financial involvement, the Kano twins were in no way "their patient", they were Aird's, and his argument that "part of our responsibility was to a great public company" was unacceptable to many. ${ }^{27}$ One correspondent in The Times stated, "A doctor is expected so to act that the general public will feel assured that he and his colleagues will regard the patient's best interests as of paramount importance irrespective of pressure applied by outside parties or of economic, racial or religious considerations". ${ }^{28}$ The decision to use the services of a commercial company as an intermediary was also criticized by contemporaries. ${ }^{29}$ John Pringle, the BMA's press and public relations man,

\footnotetext{
${ }^{24}$ Ibid., p. 193.

${ }^{25}$ Records of the Joint Conference, 26 July 1955 , Press 25-26 July and general memos.

${ }^{26}$ I Aird letter to Br.med.J., 1954, i: 153, emphasis added.

${ }^{27}$ Ibid.
}

\footnotetext{
${ }^{28}$ Records of the Joint Conference, 12 July 1955, PR (press) 3, correspondence in The Times, 'Profession and the press', letter from R Forbes, Secretary of the Medical Defence Union, 1 March 1955.

${ }^{29}$ McLeave, op. cit., note 9 above, p. 179.
} 


\section{Kelly Loughlin}

was one of the first to respond to Aird's Observer interview and its condemnation of the press, pointing out that the services of his press office had been offered during both cases and not taken up. ${ }^{30}$ Journalists covering medicine and the NHS wrote to the British Medical Journal, expressing their surprise that Pringle had been turned down in favour of a commercial company, suggesting this decision might account for the poor management. ${ }^{31}$ Moreover, from available accounts it seems that Aird was much more active in seeking to manage the press than was the UAC, and it could be argued that the BMA's press office would have restricted his activity.

It was Aird who arranged a press conference in which journalists were allowed to question and photograph the mother of the twins, and some journalists reported his willingness to talk to "reputable" members of the press. ${ }^{32}$ Furthermore, and despite his expressed contempt for those publications bidding for an exclusive interview with the mother, it was Aird who brokered a deal with a magazine for her story-the $£ 100$ proceeds went to the family. ${ }^{33}$ Aird's involvement with the press is understandable, as public representations of the case were inevitably representations of his standing as a surgeon. In many respects this was his story: "Hundreds of letters reached the Professor's officefrom groups of people in factories and offices, from friends and former patients, from ordinary members of the public. In Nigeria, special prayers were said for the Professor". 34 This extract from Aird's biography conveys the sense of drama and expectation that surrounded the Kano operation, whereby "Aird and his staff felt as though they were taking their professional lives in their hands; it was as though they had chosen to operate in front of the BBC television cameras at Lime Grove a few hundred yards from their hospital". 35 This impression was understandable given that the operating theatre was packed to capacity with surgical teams, a large medical audience and a full film crew. When preparing for the operation, Aird viewed a Canadian film of an unsuccessful attempt at separation and arranged for his own attempt to be recorded for posterity. The film was later screened at a special meeting of the Royal Society of Medicine and, although two full surgical teams participated in the operation, Aird's voice provided the commentary. ${ }^{36}$ The film and the equally crafted clinical report to the medical journals were formats in which Aird controlled the story of his groundbreaking operation-the shape of the narrative and the timing of its release. ${ }^{37}$ Media interest undermined this control, by raising expectations and framing the narrative in terms of success or failure.

The Keighley twins presented a very different situation, with more socially powerful parents and a much lower chance of either child surviving surgery. There was no film or

\footnotetext{
${ }^{30}$ Letter from John Pringle, The Times, 2 March 1955, p. 9.

31 'Press publicity', letter from John Prince, Br. med.J., 1954, i: 216; 'Doctors and the press', letter from Alfred Byrne, Br. med. J., 1955, i: 791-2.

${ }^{32}$ On the photographs, see McLeave, op. cit., note 9 above, p. 189, and Aird's response to medical correspondent Alfred Byrne, letter from I Aird, $\mathrm{Br}$. med.J., 1955, i: 1028-9. Aird's off the record briefings of some journalists are also mentioned by R Bedford, science reporter for the Daily Mirror at the time of the Kano twins, R Bedford, 'Medicine and the
}

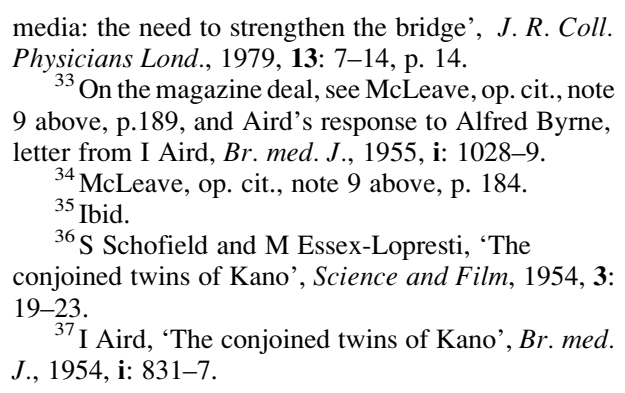

${ }^{33}$ On the magazine deal, see McLeave, op. cit., note 9 above, p.189, and Aird's response to Alfred Byrne, letter from I Aird, Br. med. J., 1955, i: 1028-9.

${ }^{34}$ McLeave, op. cit., note 9 above, p. 184.

${ }^{35}$ Ibid.

${ }^{36} \mathrm{~S}$ Schofield and M Essex-Lopresti, 'The conjoined twins of Kano', Science and Film, 1954, 3: 19-23.

${ }^{37}$ I Aird, 'The conjoined twins of Kano', Br. med. J., 1954, i: 831-7. 


\section{Press Coverage of Conjoined Twins in 1950s Britain}

published clinical report of this operation. Given the expected outcome for the girls it is easy to understand Geoffrey Knight's retreat in the face of press interest similar to that attracted by Aird at Hammersmith. The Brook Hospital received an estimated 300 telephone calls on the day the children were believed to be there, and by midday some thirty reporters were at the gates. ${ }^{38}$ Confidentiality was demanded and expected by the Keighley family, and it was the inability to keep this secret that prompted Aird's named interview in the press, and was a key issue in the Joint Conference. In effect, Aird sacrificed his professional anonymity (the named interview) in defence of patient confidentiality. This tactic demonstrates the nature of the relation between anonymity and confidentiality in the context of the 1950s. Following David Vincent's study of secrecy as "blocked communication", anonymity and confidentiality can be seen as performing the same function, that of withholding information, an act which becomes "at once a claim to probity and a demand for deference-it implies a sense of responsibility which arises from and defines a position of moral authority". ${ }^{39}$ In one sense therefore, Aird's sacrifice was a means of enhancing the moral rectitude required of a keeper of secrets.

In the eyes of the Joint Conference however, it is arguable whether Aird's tactic was entirely successful. It has already been noted that members of the conference expressed concern at what they saw as Aird's different attitude towards confidentiality in the Kano and Keighley cases - and it is difficult to read certain passages in the memorandum without thinking of Aird, "a patient's illness ought to be the patient's own personal secret, where he [sic] wishes secrecy and where secrecy can be maintained. In no way is the secret the personal 'property' $\ldots$ of his medical attendants, of the nurses or of the hospital authorities". ${ }^{40}$ The memorandum went on to suggest co-operation in "exceptional cases", namely:

take the Press into the hospital's confidence and explain frankly why publication would not be in the patient's interest or is, for some other cogent reason, undesirable. To refuse information when no good reason exists, or to show an obstructive attitude in dealing with Press inquiries ... is unwise and harmful to the interests both of the patient and of the hospital service. ${ }^{41}$

The regulation of the conduct of Aird or any other physician was not the job of the Conference or the routine procedure, professional ethics were a matter for the GMC and to a lesser extent the BMA proper. There is no evidence that Aird was formally censured for his media appearances, reinforcing the impression amongst medicine's rank and file that the profession's élite were exempt from the edict against indirect advertising. Ritchie Calder, a journalist and Chair of the Association of British Science Writers, noted that, "journalists, like the public, do not quite understand why certain doctors when they attain eminence seem to be outside this ethic, and, while not directly encouraging publicity, do not exactly discourage it". ${ }^{42}$ A subsequent letter to the British Medical Journal added that,

\footnotetext{
${ }^{38}$ Records of the Joint Conference, 12 July 1955 , PR (press) 20, report by Dr Armstrong (Brook Hospital).

${ }^{39}$ David Vincent, The culture of secrecy: Britain, 1932-1998, Oxford University Press, 1998, p. 15.
}

\footnotetext{
40 'Doctors and the press', explanatory memorandum, Br. med. J., 1955, ii: supplement, pp. 100-2, p. 101 .

${ }^{41}$ Ibid., p. 102.

42 'Press publicity', letter from R Calder, $B r$. med. J., 1954, i: 271-2, p. 272.
} 


\section{Kelly Loughlin}

"The profession at large are equally puzzled". ${ }^{43}$ The élite in this context were hospital consultants and/or society doctors with notable clients, such as Churchill's doctor Lord Moran. As the terms of the memorandum and the routine procedure clearly indicate, the BMA's chief role in the Conference was to represent members of the profession working in hospitals. That the routine procedure was addressed specifically to "news from hospitals" provides a clear indication that issues of medical communication raised by the Kano and Keighley cases were part of the professional and organizational tensions of the young NHS.

\section{Secrecy in a New Context}

The early decades of the NHS were marked by a number of professional and organizational tensions. A key matter of concern was the growing division in resources and status between acute hospital services and what would now be described as primary care services, such as general practice. ${ }^{44}$ Furthermore, the rise of the NHS consultant took place in a context where questions of administration and organization were an on-going problem. ${ }^{45}$ The prominence of such issues points to the significance of the transformation wrought by the NHS, which altered the ownership of hospitals and professional relationships within and beyond their walls. Hospitals with different management structures and different traditions, which had formed an essentially local pattern of hospital provision, were now brought within a national service. ${ }^{46}$ These matters were a recurrent theme in BMA discussions and the controversy over hospitals and the press took place in the midst of these changes. Evidence presented to the Joint Conference spoke directly to these tensions. One participant, the Newspaper Society, produced results from a survey it had conducted on relations between the hospitals and the provincial press: "We are very hurt by the development, in some areas, of what amounts to a state of 'cold war' between hospitals and the local press". ${ }^{47}$ Medical and media spokesmen stated the value of strong links with the press during the period of the voluntary hospitals. The Guild of British Newspaper Editors claimed: "Before the National Health Service, relationships between newspapers and hospitals were altogether cordial ... The newspapers had played a great and honourable part in raising money for the voluntary hospitals, and the hospitals repaid them by co-operating in every reasonable way." 48

Nationalization was identified as the culprit, particularly the distant attitude of new management committees and a lack of clarity about who could, or indeed whether anyone should, speak to the press. Evidence of confusion and the state of cold war was presented to the Conference by a reporter who tried to cover the Keighley case for a national newspaper:

From the moment the story broke in the stop press of the Bradford Telegraph \& Argos reporters were confronted with officialdom at its worst. The story itself began with a denial that the twins had

\footnotetext{
43 'Press publicity', letter from J Clapham Coates, Br. med. J., 1954, i: 518.

${ }^{44}$ I Loudon, J Horder and C Webster (eds), General practice under the National Health Service, 1948-1997, Oxford, Clarendon Press, 1998.

${ }^{45} \mathrm{C}$ Webster, The health services since the war, vol. 2: Government and health care, the National Health Service, 1958-1979, London, The Stationery Office, 1996; G Rivett, From cradle to grave: fifty years of the NHS, London, King's Fund, 1999.
}

\footnotetext{
${ }^{46} \mathrm{C}$ Webster, 'Local government and health care: the historical perspective', Br. med. J., 1995, 310: 1584-87.

${ }^{47}$ Records of Joint Conference, 12 July 1955, PR (press) 4, Hospitals and the press, contains transcript of meeting with the press 29 March 1955 , contribution by $\mathrm{J}$ L Palmer of the Newspaper Society.

${ }^{48}$ Ibid., statement by D Prosser, Guild of British Newspaper Editors.
} 


\section{Press Coverage of Conjoined Twins in 1950s Britain}

been born at all. Statements were made by the Medical Officer of Health and the Town Clerk of Keighley. One said, "No twins have been born", the other said, "We cannot say anything about it at the moment." 49

The hospital, like the other official sources he approached, was neither willing to confirm or deny the birth. The journalist then made enquiries in the town and identified women who had recently given birth in the hospital. In this way he discovered the name of the twins' mother, but not the address of the family. Finally he sought out hospital cleaners and porters who confirmed the facts of the case and divulged that the children had left Keighley and were going to be separated. The family's address was finally established from the town's electoral register. At this stage the reporter returned to the hospital for a promised press conference, which never materialized.

The claims of newspaper organizations point to a change in the dependency of the relationships between hospitals and their local press. Testimony supplied by an individual journalist, taken alongside other accounts of "the press and the twins", suggests that an absence of official information resulted in reporters having greater recourse to different sources (cleaners) and different kinds of information (news about the doctor as replacement for news about the patient). This begs the question of why the hospital had become problematic as a source of news? One element present in debates about coverage of the twins, which suggests a significant constraint on the hospital as news-source, was an insistence on anonymity for the hospital as well as the surgeon, a kind of extended anonymity. This is apparent in Aird's comments about the UAC's press office improving the situation regarding the Kano twins, where he states that had they been used earlier "my hospital and I could have remained anonymous". Indeed, in his promotion of such intermediaries, he saw them as providing a route "for hospitals to provide the press anonymously with a certain amount of information". Likewise, the routine procedure described an obstructive attitude to the press as "harmful to the interests both of the patient and the hospital service", not individual hospitals or doctors. ${ }^{50}$ It seems that the rule against indirect advertising, which sought to eliminate unfair advantage, had been stretched to include individual hospitals.

This stretching of anonymity developed post-NHS; as delegates to the Conference noted, publicity was an essential part of most hospitals before $1948 .^{51}$ The idea of an anonymous hospital acting as a source of news was clearly not practicable or achievable. Moreover, the credence given to the idea of extended anonymity points to the ambiguity surrounding the communicative possibilities of NHS hospitals. A pattern of local press relations may well have broken down with the advent of the national service. The routine procedure was therefore an attempt to re-build these relations by offering practical suggestions and guidelines on the ethical principles governing release of patient information. After all, the issue of communicative authority and more general matters of information control had

\footnotetext{
${ }^{49}$ Records of the Joint Conference, 29 March 1955, Exploratory meeting held 29 March 1955, notes for advance meeting of medical side (private and confidential, PR (press) B, summary of preceding events, confidential report from a staff reporter.

50 'Doctors and the press, news about hospital patients', Br. med. J., 1955, ii: supplement, p. 102.
} 


\section{Kelly Loughlin}

not been sufficiently addressed in the planning and implementation of the new service. Modes of information control (confidentiality, anonymity) were the core of medicalethical debate at this time. In the context of nationalized hospitals and a salaried medical service, this oversight constituted a highly productive space in which the authority of the medical profession could be publicly enacted.

Disputes regarding ownership of and access to medical records had emerged in relation to the introduction of National Insurance in the early part of the century, and these conflicts continued with the development of the NHS. ${ }^{52}$ The sanctity of the doctor-patient relationship and the ethical bonds that structured it were increasingly brought to the fore postNHS. ${ }^{53}$ The issue was plainly stated in a British Medical Journal editorial about publicity arising from 'Doctors on the air' in 1956:

There has been a drift away from traditional medical ethics since the introduction of the NHS ... if this is not checked the profession will insensibly lose its own self respect, and the respect of the public which clamours for sensation and the vulgarity of personal publicity. Now that one of the great professions is in the grips of a State-provided service-is to all intents and purposes nationalized - it must hold fast more firmly than ever to the decencies of professional behaviour. ${ }^{54}$

This could be read as so much bluff and bluster, the BMA reaching for the moral high ground of professional ethics. However, the Joint Conference, and the saga of the twins indicates a good deal of confusion about managing medical secrecy (the essence of the professional ethic) within the context of the hospital service.

Part of the "traditional medical ethics" referred to above was a model of medical confidentiality based on an individual doctor engaged in a private and enclosed relationship with an individual patient. The significant exception to this was legislation on notifiable diseases, but apart from this the model remained intact throughout much of the post-war period. And yet Aird himself spoke of the difficulty of maintaining secrecy in a modern hospital, "leakage is almost inevitable in a community where many of the relevant medical facts are known to hundreds of people" ${ }^{55}$ He argued that such leaks affected the morale of staff and created an atmosphere of suspicion. This point was echoed at the opening of the Joint Conference by the chair of the medical side, Sir Guy Dain, who stated:

We are in further difficulty in regard to the leakage of personal details of hospital cases because although nurses accept the same standards of secrecy as doctors ... that does not necessarily apply to all hospital staff. There are very large staffs of people of all kinds, such as porters and others, who may pick up news and there is risk that they, as amateurs or paid informants, may spread news which is incomplete or garbled. ${ }^{56}$

The large, modern hospital presented the problem of extended confidentiality. This problem found its clearest expression some two decades later, in BMA evidence to the

\footnotetext{
${ }^{52}$ Report of BMA's CEC, including section on "professional secrecy", where the ethical problems raised by government departments seeking access to medical records, 'Medical ethics', Br. med. J., 1951, i: supplement, pp. 260-1; see also 'Professional secrecy', Br. med. J., 1952, ii: supplement, pp. 52-3.

${ }^{53} \mathrm{D}$ Armstrong, 'The doctor-patient relationship, 1930-80', in P Wright and A Treacher (eds), The problem of medical knowledge: examining the
}

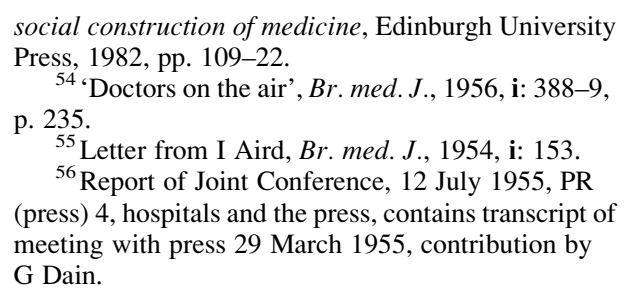
meeting with press 29 March 1955, contribution by G Dain. 


\section{Press Coverage of Conjoined Twins in 1950s Britain}

Younger Committee on Privacy (1972). Here, it was deemed no longer practical to look upon the single physician as the patient's sole confidant in a serious illness, "it is assumed by public and profession alike that any contact with the complex medical machinery of today implies acquiesence in some degree of extended confidence" ${ }^{57}$ This is not to suggest that the NHS created the problem of extended confidentiality. After all, medical officers of life assurance firms and panel doctors providing certification for sickness benefit all compromised on confidentiality - to a certain extent. In the 1950s however, this problem was highlighted for specialists in the context of the new hospital system.

Concern about leaks and paid informants (cleaners, porters) amongst hospital staff was a particular theme during this controversy. The "disreputable" nature of these employees, along with their low socio-economic status stood in stark contrast to gentlemanly doctors, seeking to keep their ethical code despite the fact that "they're employees now ... either full-time salaried or receiving payments for their services at hospitals ... [T] hey were voluntary workers, but now they are employees of the hospital". ${ }^{58}$ A gentlemanly and class-cultural concern with public clamour for sensation and vulgarity found a ready audience at this time, due to developments within the press. The 1950s saw moves towards greater professionalization within journalism, indicated by the emergence of specialist reporters covering fields like medicine and the NHS; mentioned above. Equally significant were other post-war developments like the formation of the Association of British Science Writers (1947); a professional association of specialist reporters. ${ }^{59}$ The General Council of the Press also came into being at this time (1953) as an outcome of the first Royal Commission on the Press (1947-9). ${ }^{60}$ The Press Council issued its first report in October 1954, and although the Council did not meet the expectations of many, its appearance and publications served as a focus for debate about press standards. Indeed, one of the Council's first statements was on the conjoined twins, not surprising considering that its Chair, Sir Linton Andrews, was a member of the Joint Conference. ${ }^{61}$

In a letter to the Daily Telegraph entitled 'Jackals of the Press', the Earl of Selborne launched a particularly scathing attack on the popular press. Amidst his demands that the Press Council be given teeth, medical reporting was linked with rumour and scandal:

These organs [the gutter press] specialize in exploiting every conceivable morbid sensation, whether it can be extracted from the scum of the police courts, from divorce proceedings, from murders and other crimes ... from accidents or even operations and confinements ... They pry into hospital wards and subject surgeons, engaged in the most critical cases, to third degree interrogations. ${ }^{62}$

\footnotetext{
${ }^{57}$ Vincent, op. cit., note 39 above, p. 235.

${ }^{58}$ Records of Joint Conference, PR (press) 4, Report of meeting 29 March 1955, statement by Dr Woolley.

${ }^{59}$ On the development of specialist reporters covering medicine, see K Loughlin, 'Networks of mass communication: reporting science, health and medicine from the 1950s to the 1970s', in Berridge (ed.), op. cit., note 7 above, pp. 297-323.

${ }^{60}$ T O'Malley, 'Demanding accountability: the press, the Royal Commissions and the pressure for reform, 1945-77', in M Bromley and H Stephenson (eds), Sex, lies and democracy: the press and the public, London, Longman, 1998, pp. 84-96.
}

\footnotetext{
${ }^{61}$ The statement was issued on 8 March 1955, a copy is contained in the documentation of the Records of the Joint Conference, Exploratory meeting held 29 March 1955, notes for advance meeting of medical side (private and confidential) PR (press) 2: "[The Council] recognises that serious ethical questions are involved and favours the formulation of some common principles and policy in gathering and supplying news and photographs in medical cases".

${ }^{62}$ Records of the Joint Conference, Exploratory meeting held 29 March 1955, notes for advance meeting of medical side (private and confidential), PR (press) B, summary of preceding events; PR
} 


\section{Kelly Loughlin}

Andrews himself caused a flurry of letters in The Times when he characterized the activities of freelance reporters in the following manner: "harassing of the unfortunate by unattached so-called journalists and photographers drawn into a news hunt by the prospect of rich returns if they can get scoops by their audacity". ${ }^{63}$ Representatives of these journalists refuted this description and pointed to the directories of freelance reporters maintained by the National Union of Journalists and a similar register held by the Institute of Journalists. ${ }^{64}$ The image of the scoop-driven freelance was the media counterpart to the secret-spilling hospital porter. Such people may well have played a part in the publicity surrounding the twins, but they were not the crux of the problem. In many respects these figures can be seen as caricatures of broader patterns of change in medicine and in the press.

\section{Conclusion: Medicine and the Media Circus}

Conjoined twins have always aroused public curiosity: as spectacle for public exhibition and more recently as part of the spectacle in high risk and increasingly contested surgical intervention. However, the claims and counterclaims mobilized in relation to the 1950s cases were highly context specific and time-bound. The material presented here demonstrates that the crux of the dispute over media coverage of the twins was centred precisely on the nature of source-media relations: the role of doctors and hospitals as sources of popular news. Questions raised by medicine as popular news were framed as ethical questions during the 1950s. Rules surrounding medical communication, especially the idea of patient confidentiality, have a long history. ${ }^{65}$ However, controversy about press coverage of the conjoined twins provides an example of the way these ethical rules have changed over time and in response to new circumstances: a point raised by Roger Cooter in his review of histories of medical ethics. A concern with ethics comes to the fore in medicine at moments when "individual practitioners or the profession as a whole felt their social and legal status and authority under threat". 66 This has been shown in studies of eighteenth-century British medicine, when rapid institutional, commercial and organizational change began to pose "fresh problems regarding professional power, collective responsibility, and the division of labor". 67

Professional-ethical concern over communication, publicity and especially advertising seems to surface at times when medical practitioners experience such threats to social status, professional and economic power. For example, the edict against advertising, which emerged at the close of the nineteenth century, was largely a response to the perceived

(press) $\mathrm{C} 3$, comments and correspondence in the press, British Medical Journal, The Times, Daily Telegraph, general press comment, miscellaneous: 'Jackals of the Press', letter to Daily Telegraph from Earl of Selborne, 11 March 1955.

${ }^{63}$ Ibid., PR (press) C3, comments and correspondence in the press, correspondence in The Times, letter from Sir Linton Andrews, 3 March 1955.

${ }^{64}$ Ibid., PR (press) C3, comments and correspondence in the press, correspondence in The Times, letter from L G Rule, Chair, London Branch of the National Union of Journalists, 5 March 1955; letter from Brian R Roberts, President, Institute of Journalists, 8 March 1955.

${ }^{65}$ A McLaren, 'Privileged communications: medical confidentiality in late Victorian Britain', Med. Hist., 1993, 37: 129-47.

${ }^{66}$ Cooter, op. cit., note 3 above, p. 262.

${ }^{67} \mathrm{R}$ Baker, D Porter and R Porter (eds), The codification of medical morality. Vol. 1: Medical ethics and etiquette in the eighteenth century, London, Kluwer Academic Press, 1993, p. 9. 


\section{Press Coverage of Conjoined Twins in 1950s Britain}

threat posed by quacks, patent medicine and irregular practitioners who plied their trade in the media. The response was class-cultural, an act of professional closure in which claims to a gentlemanly profession deemed advertising to be unethical due to its association with the market. Interestingly, competition from alternative practitioners also played a part in the erosion of the advertising ban for medical specialists in the 1990s. General practitioners have been able to advertise directly to the public since 1990. When this privilege was extended to specialists in 1996, part of the reason was the threat of non-medical practitioners:

[D]octors who wanted to advertise such services as screening or acupuncture were regarded as specialists and so could not advertise directly to the public. These doctors often complain that the existing guidance is potentially damaging to patients because non-medically qualified practitioners are able to advertise the same services. ${ }^{68}$

In the context of the 1950s, a period characterized by the bedding down of the new service, ethical debate focused on communication and its relationship to the profession's authority. The routine procedure sought to clarify ownership of the "secret" of a hospital confinement: to what extent did it belong to the patient, physician or hospital. The outcome of the Joint Conference was a clear articulation of the idea that an individual patient owned the story of their illness - it was in no way the property of the physician or hospital. However, patients could and did break the rules, compromising the physician's role as keeper of secrets, "If we withhold information, they give it — and so do their friends and neighbours". ${ }^{69}$ Concurrent with this was the further erosion of medical authority signalled by extended confidentiality: where secrets are known not only to the physician, but to a vast array of hospital employees. These debates about medical communication and professional ethics are indicative of the new social relations brought into being by the NHS. By comparison with other members of the profession, hospital consultants did very well in the context of the NHS, but one should not overlook the scale of the transformation in relationships between hospital doctors and their patients: they were "employees now". 70

Change in the social relations between doctors and patients, hospitals and the public was a theme present in contributions to the debate about medical secrecy, "every citizen should feel a full sense of responsibility for [the service] ... [this] cannot develop unless the administrative and medical powers-that-be take the public into their confidence, stop being secretive ... and start inviting consumers to offer their suggestions". ${ }^{71}$ The role of the press in facilitating a new relationship between the public and the profession was equally to the fore in these debates: reflecting change within the media as well as medicine, "The public would appreciate and benefit from more information about the medical services ... The press could be a vital link". ${ }^{72}$

Like medicine, the British press experienced significant development in the organization of reporting practices and the management of information during the 1950s. The decade saw a growth in public relations and journalists specializing in science and medicine.

\footnotetext{
68 'UK specialists to be allowed to advertise', letter from L Beecham, Br. med. J., 1996, 313: 1226-27, p. 1227.

69 'Doctors and the press', letter from W Edwards, Br. med. J., 1955, i: 791 .
}

\footnotetext{
${ }^{70}$ Armstrong, op. cit., note 53 above.

71 'Press publicity', letter from S Swingler, Br. med. J., 1954, i: 644-5, p. 645, emphasis added.

${ }^{72}$ Letter from D Morris, Br. med. J., 1954, i: 272 .
} 


\section{Kelly Loughlin}

In later decades the close links between medical journalists and the public relations function of medical organizations, such as the BMA, would come under scrutiny. ${ }^{73}$ In the context of the 1950s however, such links were championed as the way forward. Aird's independent stance, in refusing the help of John Pringle, was criticized by new specialist reporters, such as John Prince and Alfred Byrne, who saw the BMA press office as, "the clearing-house for an immense amount of reliable medical information which is given promptly to the Press ... [and] promotes the best possible relations between the profession and the Press". ${ }^{74}$ Public relations developed later in the NHS and throughout individual hospitals, although the subject of news from hospitals was guided by the routine procedure through to the $1990 \mathrm{~s}^{75}$

Old and new perspectives can be identified in the battle to control the telling of stories and keeping of secrets in the Kano and Keighley cases. During the 1890s two young girls born in India in 1889, Radica and Doddica, toured Europe as the conjoined twins the "Orissa Sisters". One child contracted tuberculosis and they were subjected to separation surgery in an attempt to save at least one. The Parisian surgeon, Dr Doyen, attempted the operation. According to one version of the story, contained in the aptly titled Victorian Grotesque:

the exercise was carried out in the wildest blaze of publicty-Doyen was known as the "Barnum of surgery". A promoter proposed that the operation should be done in the Cirque de Paris as the climax of a charity gala allegedly in aid of the girls. Certainly the operation was the first to take place with each stage being recorded by cameras. Dr Doyen was duly photographed making the first incision $\ldots$ and the sisters died amid the glare of flash-powder. ${ }^{76}$

Publicity surrounding the surgical separation of conjoined twins dates back at least as far as Doyen's incision on Radica and Doddica, and continues through to the death of Iranian sisters Ladan and Laleh Bijani in July 2003. This continuity however, should not mask the specifics of time and place, which shape the telling of stories and keeping of secrets in high-risk, high-profile surgical interventions.

\footnotetext{
${ }^{73}$ K Loughlin, 'Networks of mass communication: reporting science, health and medicine from the $1950 \mathrm{~s}$ to the 1970s', in Berridge (ed.), op. cit., note 7 above, pp. 297-323.

74 'Doctors and the press', letter from A Byrne, $B r$. med. J., 1955, i: 791-2.

${ }^{75}$ See, for example, R Silver (ed.) Health service public relations, a guide to good practice, London, King Edward's Hospital Fund, 1985.
}

This text, which went to a second edition in 1995 , reproduced the routine procedure as an appendix in the first edition.

${ }^{76} \mathrm{M}$ Howard, Victorian grotesque: an illustrated excursion into medical curiosities, freaks and abnormalities - principally of the Victorian age, London, Jupiter Books, 1977, p. 26. On Doyen see, R Didier, Le Docteur Doyen: chirurgien de la Belle Epoque, Paris, Maloine, 1962. 